Ulasan Film

\title{
Bidadari Halmahera: Hirarki Gender dalam Kisah Romansa Primadona Desa
}

\section{Sepril Melani Ubyaan}

Universitas Kristen Indonesia
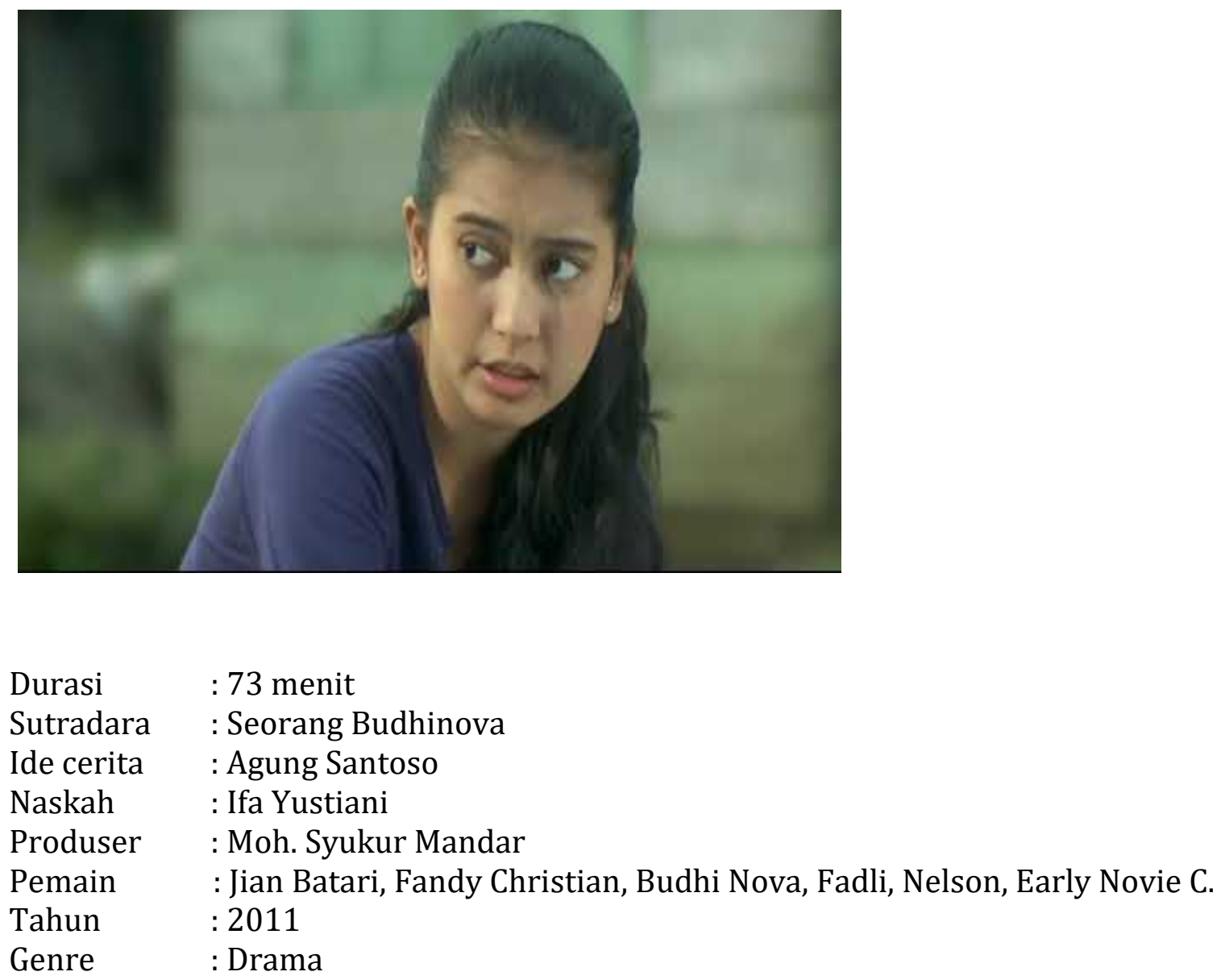

Korespondensi Penulis:

Sepril Melani Ubyaan, Kristen Indonesia, Jakarta

E-mail:seprilmelani@yahoo.com 


\section{Drama Asa dan Cinta Gadis Halmahera}

Bidadari adalah nama seorang gadis yang tinggal di Halmahera Utara. Halmahera Utara adalah nama satu kabupaten kecil di Provinsi Maluku Utara, Indonesia, yang memiliki cukup banyak penduduk dan berpenghasilan utama kopra atau kelapa, cengkeh, dan sagu. Bagi yang ingin berkunjung ke sana, wilayah Halmahera dapat diakses melalui jalur laut dan udara.

Tokoh utama dalam film ini, gadis bernama Bidadari, adalah seorang anak yang dibesarkan oleh keluarga sederhana di suatu desa terpencil di Kabupaten Halmahera. Bapak Bidadari adalah seorang petani kopra (kelapa) seperti sebagian besar penduduk di Halmahera lainnya. Tanah Maluku secara keseluruhan berhiaskan pohon kelapa dan sedikit cengkeh dan sagu. Itulah hasil pertanian daerah Maluku.

Dibesarkan di keluarga yang sederhana tidak memadamkan impian Bidadari untuk mengenyam pendidikan hingga ke perguruan tinggi. Bidadari bermimpi untuk melanjutkan pendidikannya ke jenjang perguruan tinggi, namun sayang impiannya itu dicekal oleh sang ayah yang berpenghasilan kecil. Kondisi lain yang menghalangi mimpi Bidadari adalah sang kakak laki-laki yang masih kuliah dan ibunya yang sedang sakit. Menghadapi kebuntuan tersebut, Bidadari merasa sangat terpukul dan sedih. Layaknya pemuda-pemudi di daerah yang pilihan profesinya masih terbatas dan cenderung diarahkan oleh orang tua untuk menjadi abdi negara, Bidadari pun lantas mencoba ujian masuk Pegawai Negeri Sipil. Namun usaha ini juga tak membuahkan hasil dan Bidadari terpaksa menganggur sambil menjaga mamanya yang sakit.

Film ini kemudian mengangkat isu pernikahan paksa dengan latar kemiskinan. Patriarki yang kuat di berbagai daerah tertinggal semakin memojokkan perempuanperempuan muda untuk menerima pinangan laki-laki yang tidak dipilihnya sendiri (Perempuan, 2016). Dalam film, selain karakter sederhana, sang tokoh utama juga memiliki paras yang cantik sehingga banyak pemuda di kampung yang ingin mendekatinya. Salah satu pemuda yang mengejar Bidadari adalah Bahim anak Pak Jamal, seorang saudagar di kampung. Dengan motif untuk mendekati Bidadari, Pak Jamal bahkan bersedia selalu meminjamkan uang kepada keluarga gadis yang rajin beribadah ini. Tujuan Pak Jamal jelas, ia hendak mengikat keluarga Bidadari dengan hutang, agar kelak putri semata wayang mereka mau dinikahi oleh anak laki-lakinya. Keseharian keluarga Bidadari memang akhirnya menjadi bergantung kepada pinjaman 
Pak Jamal setelah sepetak tanah kebun kelapa yang menjadi sumber mata pencaharian sang ayah digadaikan kepada saudagar kaya yang mempunyai maksud terselubung itu. Meski demikian, Bidadari selalu berusaha menolak setiap kali Bahim mendekati dirinya. Sikap pemuda itu yang arogan membuat Bidadari lebih memilih menjauhi keluarga Pak Jamal (Budhinova, 2011).

Tokoh cerita bertambah dengan kedatangan seorang pemuda dari kampung lain. Pemuda bernama Rizal tersebut berkuliah di Jakarta, namun dipanggil pulang oleh orang tuanya dengan maksud untuk dijodohkan. Pernikahan untuk memperkuat bisnis memang bukan hal yang sering ditemukan di desa, namun sang sutradara cukup "memaksa" demi mengembangkan konflik dalam cerita. Rizal sang pemuda yang cukup emosional itu kemudian menolak rencana pernikahan dan meminta kembali ke Jakarta. Ia ingin melanjutkan kuliahnya, namun tidak diizinkan oleh bapaknya demi tujuan memperbesar bisnis keluarga. Rizal nekat kabur dari rumah dan sampailah ia ke kampung tempat Bidadari tinggal. Mencoba untuk tidak mengandalkan orang tua, Rizal yang butuh makan dan minum, juga tempat tinggal, memilih untuk bekerja sebagai tenaga bantuan di keluarga Pak Jamal.

Suatu hari Bahim, anaknya Pak Jamal dan Rizal, yang ikut bekerja membantu, datang ke rumah Bidadari membawa hadiah untuk meraih hati gadis idaman. Di situlah Rizal melihat Bidadari dan jatuh hati padanya. Begitupun sebaliknya. Pertemuan demi pertemuan semakin mendekatkan keduanya hingga hubungan di antara mereka diketahui oleh anak Pak Jamal. Konflik percintaan cukup mengambil banyak bagian dari film ini sebelum beralih kepada konflik baru setelah Bidadari mengetahui identitas dirinya yang selama ini dirahasiakan oleh orang tuanya.

Bidadari bukanlah anak kandung, melainkan anak yang dititipkan dan kedua orang tua Bidadari telah meninggal. Selain itu, sepetak tanah kebun kelapa yang digadaikan kepada Pak Jamal pun sebenarnya juga adalah tanah warisan orang tua kandung Bidadari untuk putrinya. Usai memberitahukan hal tersebut, ibu angkat Bidadari lalu menutup mata untuk selamanya. Bidadari hanya bisa menangis menerima dua kenyataan pahit itu.

Setelah kematian sang ibu, Bidadari hanya tinggal berdua dengan bapaknya di kampung. Suatu hari Bidadari dan bapaknya diundang oleh Pak Jamal dengan maksud 
membicarakan pernikahan Bidadari dengan anaknya. Di situ Bidadari berani menolak dan berlari meninggalkan bapaknya dan Pak Jamal. Ia berlari menemui Rizal sang kekasih. Rizal sudah terlebih dahulu pergi ke Ternate baru kemudian disusul oleh Bidadari. Pada pertemuan mereka saat itu, Rizal mengatur rencana agar Bidadari meninggalkan kampungnya bersama sang kekasih. Rencana tersebut dibuat untuk menggagalkan pernikahan paksa antara Bidadari dan anak Pak Jamal. Bidadari yang polos termakan cinta sang kekasih lalu mengiyakan tanpa berpikir bagaimana akibatnya nanti. Cara yang dilakukan oleh Rizal tersebut nyata-nyata tidak menyelesaikan permasalahan yang ada; justru hal itu membuat keretakan dalam keluarga Bidadari. Pak Jamal yang selama ini membantu kehidupan sehari-hari keluarga Bidadari menjadi sangat marah apabila keinginannya untuk menikahkan Bidadari dengan anaknya terancam gagal. Dikisahkan Rizal tidak berpikir panjang bagaimana nantinya bila Bidadari hadir di Ternate, sementara Rizal sendiripun hendak dijodohkan dengan anak dari seorang relasi bisnis bapaknya.

\section{Ulasan}

Film Cinta Setulus Bidadari bercerita tentang cita-cita anak perempuan keluarga miskin di daerah pelosok Indonesia yang sebetulnya kaya akan sumber daya alam. Cita-cita mulia mengecap pendidikan tinggi harus berhenti karena terhalang ekonomi ditambah konflik percintaan dari pemudi sederhana yang terhalang hutang orang tua. Film ini mewakili kisah kehidupan perempuan di Indonesia bagian timur yang masih tergolong daerah terpencil (Sandiata, 2018). Di sebagian besar daerah tersebut, hanya orang yang berduitlah yang bisa melanjutkan kuliah. Kemewahan itupun diprioritaskan untuk anak laki-laki karena menurut pemahaman masyarakat patriarki, yang dapat ditemukan di hampir seluruh bagian Indonesia, anak laki-lakilah yang akan meneruskan garis keturunan. Jikalau seseorang ingin mengubah kelas sosial keluarganya, ia harus mengubah anak laki-laki yang kelak meneruskannya (Sakina \& A, 2017).

Perempuan tidak berkesempatan kuliah di sisi yang lain karena perempuan akan menikah dengan laki laki dari keluarga lain. Anak perempuan kelak akan pergi bersama suaminya untuk menjadi bagian keluarga pihak laki laki. Akibatnya, banyak perempuan di Indonesia timur hanya bisa bersekolah sampai jenjang SMA. Selebihnya, mereka akan tinggal di rumah dan membantu orang tua di dapur dan kebun. Masa depan perempuan 
terkait jodoh adalah peranan orang tua, terutama bapak sebagai kepala keluarga. Anak perempuan biasanya dijodohkan karena berbagai alasan, salah satunya karena hutang. Apabila seorang anak perempuan menolak, hal yang paling sering terjadi adalah ia akan pergi bersama kekasih pilihannya (kawin lari) dan diusir dari rumah.

Permasalahan yang diangkat dalam film Bidadari Halmahera adalah anak perempuan tidak mempunyai hak untuk mengatur jalan hidupnya sendiri. Dilihat dari upaya sang tokoh Bidadari, ia sendiri mencoba mengatasi masalah keluarganya dengan cara ingin bekerja di kantor swasta; tetapi tidak diizinkan oleh sang ayah. Menurut ayah Bidadari, "kesuksesan" hanya bisa didapat dengan cara menjadi Pegawai Negeri Sipil. Namun, realitanya sekarang tak hanya di Indonesia timur, tetapi bahkan hampir di seluruh Indonesia, menjadi PNS adalah sesuatu yang tidak mudah; ditambah lagi masih adanya praktik Korupsi, Kolusi dan Nepotisme yang mengutamakan calon PNS tertentu dari yang lain atas dasar kedekatan pribadi dengan segelintir orang di instansi tersebut. Hal ini semakin memperkecil peluang para perempuan untuk berkiprah sebagai pelayan publik tanpa diuji kemampuannya. Ibarat kalah sebelum bertanding, seorang perempuan muda harus bisa mengalahkan prasangka yang dilekatkan kepada mereka seperti tidak terampil dalam peran-peran di masyarakat; yang ironisnya justru dimulai oleh keluarga yang mendidik dan membesarkan mereka.

Dalam drama ini pun terlihat jelas budaya masyarakat patriaki di mana peran ibu dalam keluarga hanyalah membantu dan bukan mengambil keputusan. Ibu Bidadari hanya berperan sebagai pelindung apabila dimarahi oleh sang bapak dan tempat mengadu mencurahkan segala beban yang Bidadari rasakan tentang impiannya untuk kuliah dan masalah di percintaannya. Meskipun ditentang oleh sang bapak, namun Bidadari tidak berhenti untuk mencintai Rizal (jangan lelah perjuangkan torang dua pe cinta adalah kalimat yang sering dikatakan Bidadari dan Rizal di film ini). Sang sutradara tidak kehabisan ide, dalam rangka melakukan perlawanan terhadap budaya setempat, ia menjadikan Bidadari sebagai tokoh utama yang sangat berani dengan mengisahkan Bidadari kemudian memilih mengikuti Rizal ke Ternate. Bagian ini terlihat sedikit dipaksakan karena Bidadari adalah seorang gadis desa yang lugu dan sebalumnya ia tidak pernah pergi jauh dan sendirian.

Di daerah Indonesia bagian timur, tidak hanya hierarki gender yang masih dilestarikan (Pratiwi \& Melati, 2014); namun perbedaan kelas sosial juga masih menjadi 
masalah bagi masyarakat. Hal ini dapat dilihat dari sikap arogan sang saudagar dengan keluarga Bidadari. Saudagar itu sering kali berbicara kasar dan memarahi ayah Bidadari, sedangkan ayah Bidadari selalu tampil merendah dan tidak pernah membalas.

\section{Simpulan}

Permasalahan perempuan di Kabupaten Halmahera cukup tergambar dalam film bergenre drama ini. Meskipun sutradara tampak terlalu memaksakan ide cerita untuk mendramatisir kisah percintaan tokoh utama-seperti memunculkan tokoh ketiga dalam drama ini, yaitu Rizal, untuk menghalangi Bidadari menikah dengan Bahimnamun plot cerita secara keseluruhan telah cukup mewakili isu yang dihadapi oleh perempuan di daerah Indonesia timur. Misalnya, ada pembedaan antara anak laki-laki dan perempuan.

Dalam keluarga, anak laki laki akan selalu diutamakan. Dalam sekolah, dan perguruan tinggi juga demikian, dibandingkan dengan anak perempuan. Ini dikarenakan, menurut pemahaman masyarakat Indonesia bagian timur, pada umumnya anak laki-lakilah yang akan meneruskan marga keluarga. Sedangkan anak perempuan akan kawin keluar (istilah di Indonesia timur) menikah dengan suami dan mengikuti marga dari suami.

Hambatan berbasis gender dialami oleh Bidadari dalam dua hal: pilihan cita-cita dan pilihan pasangan hidup yang beririsan dengan hambatan struktural oleh karena kemiskinan keluarganya. Jalan keluar yang ditawarkan kepada perempuan di akhir cerita adalah lari; meski ini berarti tak mengubah hierarki gender yang merugikan perempuan dalam hal terbatasnya peran-peran sosial perempuan di masyarakat dan keluarga. Satu pesan yang tajam dan menyakitkan dari drama percintaan anak muda ini adalah kenyataan bahwa perempuan dapat dipertukarkan sebagai "ganti" pelunasan hutang keluarga merupakan satu hal yang masih lazim adanya di pelosok-pelosok Indonesia. 


\section{Referensi}

Budhinova, S. (Director). (2011). Bidadari Halmahera [Motion Picture].

Perempuan, K. (2016). Kekerasan terhadap Perempuan Meluas: Negara Urgen Hadir Hentikan Kekerasan terhadap Perempuan di Ranah Domestik, Komunitas dan Negara. Jakarta: Komnas Perempuan.

Pratiwi, A. M., \& Melati, N. K. (2014, Oktober 30). Mariana Amiruddin: Narasi Verbal Melanggengkan Hierarki Gender. Retrieved November 1, 2019, from http://www.jurnalperempuan.org

Sakina, A. I., \& A, D. H. (2017). Menyoroti Budaya Patriarki di Indonesia. Share Social Work , 71-80.

Sandiata, B. (2018, Desember 6). Konferensi Perempuan Timur 2018: Perempuan Timur Bersuara. Retrieved November 1, 2018, from http://www.jurnalperempuan.org 